\title{
PENGARUH TINGKAT PEMBATASAN PEMBERIAN PAKAN (Restricted Feeding) TERHADAP PERFORMAN AYAM BROILER JANTAN
}

\author{
H. A. Kusuma ${ }^{1}$, A. Mukhtar ${ }^{2}$ dan R. Dewanti ${ }^{2}$ \\ ${ }^{I}$ Sarjana S1, Program Studi Peternakan, Fakultas Pertanian, Universitas Sebelas Maret, Surakarta \\ ${ }^{2}$ Program Studi Peternakan, Fakultas Pertanian, Universitas Sebelas Maret, Surakarta \\ Email: Dewa_proter@yahoo.com
}

\begin{abstract}
ABSTRAK
Penelitian ini bertujuan untuk mengetahui pengaruh tingkat pembatasan pemberian pakan terhadap performan ayam broiler. Penelitian dilaksanakan di Desa Tompe, Kelurahan Jirapan, Kecamatan Masaran, Kabupaten Sragen selama enam minggu dimulai tanggal 14 September sampai 26 Oktober 2011. Penelitian ini menggunakan 100 ekor ayam broiler jantan strain New Lohmann. Rancangan yang digunakan dalam penelitian adalah Rancangan Acak Lengkap (RAL) pola searah dengan empat perlakuan. Keempat perlakuan tersebut adalah P0 (pemberian pakan secara penuh tanpa puasa), P1 (6 hari pakan penuh dan 1 hari puasa), P2 (5 hari pakan penuh dan 1 hari puasa) dan P3 (4 hari pakan penuh dan 1 hari puasa). Masing-masing perlakuan terdiri dari lima ulangan. Pakan terdiri dari BR 1 dan BR 2. Peubah penelitian yang diamati adalah Pertambahan Bobot Badan, Konsumsi Pakan, Konversi Pakan, Efisiensi Pakan, dan Income Over Feed Cost. Hasil penelitian menunjukkan bahwa rerata dari keempat macam perlakuan yaitu P0, P1, P2 dan P3 berturut-turut untuk Pertambahan Bobot Badan adalah 81,37; 74,47; 72,65; dan 72,50 g/ekor/hari, Konsumsi pakan 137,94; 126,46; 124,06; dan 119,11 g/ekor/hari, konversi pakan sebesar 1,70; 1,70; 1,71; dan 1,64. Rata-rata Income Over Feed Cost adalah sebesar Rp. 8.757,26; Rp. 8.014,98; Rp.7.818,14 dan Rp.7.808,57. Hasil analisis variansi untuk Pertambahan Bobot Badan dan Konsumsi Pakan berpengaruh sangat nyata $(\mathrm{P}<0,01)$, sedangkan Konversi pakan berbeda tidak nyata. Dari hasil penelitian ini, dapat disimpulkan bahwa tingkat pembatasan pemberian pakan berpengaruh sangat nyata terhadap Pertambahan Bobot Badan dan Konsumsi Pakan Ayam Broiler.
\end{abstract}

Kata kunci: Ayam broiler jantan, performan, pembatasan pakan

\section{The Effect of Restricted Feeding Rate on The Male Broilers Performance}

\begin{abstract}
This study aims to determine the effect of restricted feeding rate on the broiler chickens performance. The research was carried out in Tompe, Jirapan Village, Masaran Sub District, Sragen Distric for six weeks beginning from September $14^{\text {th }}$ until October $26^{\text {th }}$, 2011. This study used 100 male broiler chickens New Lohmann strain. The research design used Completely Randomized Design (CRD) one way trafic with four treatments. The fourth treatments are: PO (full feeding without fasting), P1 (6 days full feeding and 1 day fasting), P2 (5 days full feeding and 1 day fasting) and P3 (4 days full feeding and 1 day fasting). Each treatment consisted of five replicates. Feed consisted of BR1 and BR2. The Parameters observedare Body Weights Gain, Feed Consumption, Feed Conversion, and Income Over Feed Cost. The results showed that the average of four treatment are PO, $P 1, P 2$ and $P 3$ respectively for body weight gain are 81.37; 74.47; 72.65, and 72.50 grams / head / day, feed intake are 137.94; 126.46; 124.06; and $119.11 \mathrm{~g} /$ head / day, feed conversion are 1.70; 1.70; 1.71, and 1.64, feed efficiency are 0.59; 0, 59; 0.59, and 0,61. The average of Income Over Feed Cost are $R p .8 .757,26 ; R p .8 .014,98 ; R p .7 .818,14$; and $R p .7 .808,57$. The analysis of variance results for body weight gain and whole consumption has significant effect $(P<0.01)$, conversionwas not
\end{abstract}


affected. From these results it can be concluded that the rate of feeding restricteds is significantly affect on body weight gain and feed consumption of Broiler Males.

Keywords: Broiler males, performances, restricted feeding

\section{PENDAHULUAN}

Ayam broiler merupakan jenis ayam ras unggulan hasil persilangan antara bangsa-bangsa ayam yang memiliki produktivitas tinggi, terutama dalam memproduksi daging. Keunggulan jenis ayam ini yaitu hanya dalam waktu lima sampai enam minggu pemeliharaan ayam sudah dapat dipanen, dengan bobot badan rata-rata 1,3 - 1,6 kg (Rasyaf, 1994).

Pakan merupakan masalah yang paling utama pada setiap usaha peternakan. Penghematan biaya pakan merupakan tujuan yang harus dicapai agar mendapat keuntungan yang maksimal dari hasil produksinya. Menurut Suprijatna, et al., (2005) pada usaha peternakan, pakan berperan sangat strategis. Ditinjau dari aspek ekonomis, biaya pakan sangat tinggi, mencapai $70 \%$ dari total biaya produksi. Ditinjau dari aspek biologis, pertumbuhan dan produksi maksimal tercapai bila kualitas dan kuantitas pakan efisien. Produksi efisien akan tercapai bila tersedia pakan yang murah dengan kebutuhan zat-zat makanan yang terpenuhi. Usaha peningkatan produksi ternak dapat dilakukan dengan pemilihan bibit yang baik, dan penyediaan ransum yang cukup kuantitas dan kualitasnya.

Kenaikan harga pakan sering tidak seimbang dengan harga produksi peternakan ayam, sehingga menyebabkan kelesuan peternak dalam meneruskan usahanya. Memilih cara pemberian pakan pada usaha peternakan ayam merupakan faktor yang sangat menentukan bagi keberhasilan peternak, salah satunya yaitu dengan cara pembatasan pemberian pakan (Darmawati, 2005).

Pembatasan pemberian pakan merupakan program untuk memberikan pakan pada ternak sesuai dengan kebutuhan hidup pokoknya pada umur dan periode tertentu. Program ini didasarkan kepada asumsi bahwa pemberian pakan secara sepuasnya (ad libitum) merupakan kondisi buatan, sedangkan pembatasan pakan pada ayam broiler adalah upaya mengembalikan ternak pada kondisi alami (Santoso, 2008).

Banyak masalah yang cukup serius dan sering muncul pada pemeliharaan ayam pedaging terutama di daerah tropis, seperti kematian pada akhir pemeliharaan, perlemakan yang banyak, dan kelainan pada kaki. Salah satu cara yang dapat dilakukan untuk mengatasi masalah tersebut adalah dengan pembatasan pakan, apakah dilakukan di awal pertumbuhan ataupun di masa akhir pertumbuhan (Aziz et al., 2011).

Pembatasan pemberian pakan bertujuan untuk mengurangi panas metabolik yang dihasilkan dari pakan yang dikonsumsi oleh ayam. Program yang membatasi pertumbuhan awal ayam pedaging secara luas digunakan untuk mengurangi angka kematian, dan juga untuk meningkatkan konversi pakan (Dozier, et al., 2002, cit. Azhar, 2010). Selain itu juga ayam broiler yang dibatasi pakannya menunjukkan efisiensi pakan yang lebih baik dan terjadi penurunan kandungan lemak tubuh. Keuntungan lain yang dapat diperoleh dari program pembatasan pakan adalah dapat mengurangi angka kematian, kelainan kaki, dan penyakit metabolik, seperti: ascite, stres panas atau bahkan meningkatkan daya kekebalan tubuh terhadap penyakit. Program pembatasan pakan juga menaikkan kandungan mineral tubuh serta menurunkan trigliserida dan kolesterol darah dan kadar lemak dalam tubuh dan daging (Santoso, 2008).

Berdasarkan hal tersebut penulis tertarik untuk meneliti pengaruh tingkat pembatasan pemberian pakan (restricted feeding) terhadap performan ayam broiler. Penelitian ini memiliki tujuan untuk mengetahui pengaruh tingkat pembatasan pemberian pakan terhadap performan ayam 
broiler dan untuk mengetahui tingkat pembatasan yang paling optimal terhadap performan ayam broiler.

\section{MATERI DAN METODE}

\section{Tempat dan Waktu Penelitian}

Penelitian dilakasanakan di kandang ayam yang berlokasi di Desa Tompe, Kelurahan Jirapan, Kecamatan Masaran, Kabupaten Sragen. Penelitian ini dimulai pada tanggal 14 September sampai dengan 26 Oktober 2011. Pemeliharaan ayam broiler dilakukan selama 42 hari.

\section{Bahan dan Alat Penelitian}

Bahan dan alat yang digunakan dalam penelitian ini meliputi : a) Ayam broiler. Penelitian menggunakan DOC jantan strain New Lohmann MB 202 sebanyak 100 ekor. b) Ransum. Penelitian menggunakan pakan BR 1 dan BR 2 produksi PT. Japfa Comfeed Indonesia, Tbk., unit Sidoarjo. Pakan ayam pada umur 1 - 21 hari (Starter) menggunakan pakan BR 1 dan pada ayam umur 22 hari - 42 hari (Finisher) menggunakan pakan BR 2. Kebutuhan nutrien ayam broiler dapat dilihat pada Tabel 1, kandungan pakan BR 1 dan BR 2 dapat dilihat pada Tabel 2.

\section{Persiapan Penelitian}

\section{Peralatan kandang}

Tabel 1. Kebutuhan nutrien ayam broiler

\begin{tabular}{clrr} 
No. & \multicolumn{1}{c}{ Nutrien } & Starter $(1-21$ hari) & Finisher $(22-42$ hari $)$ \\
\hline 1. & Energi Metabolis (KCa1/kg) & 3200 & \\
2. & Protein Kasar (\%) & 23,00 & 3200 \\
3. & Serat Kasar $(\%)$ & 4,00 & 20,00 \\
4. & Lemak $(\%)$ & 6,00 & 5,00 \\
5. & Ca $(\%)$ & 1,00 & 6,00 \\
6. & P tersedia $(\%)$ & 0,45 & 0,9 \\
7. & Lisin $(\%)$ & 1,1 & 0,35 \\
8. & Metionin $(\%)$ & 0,5 & 1,0 \\
\hline
\end{tabular}

Sumber: NRC (1994)
Penelitian ini menggunakan 20 petak kandang litter dengan ukuran $(1,0 \mathrm{x} 1,0 \mathrm{x}$ 0,5) m. Bahan untuk sekat tiap kandang terbuat dari bambu dengan litter terbuat dari sekam. Setiap petak kandang berisi lima ekor ayam.

Peralatan kandang yang digunakan adalah : a) Tempat pakan dan tempat air minum. Tempat pakan terbuat dari bambu, Sedangkan tempat minum yang digunakan terbuat dari bahan plastik yang ditempatkan pada setiap petak kandang. b) Termometer. Termometer yang digunakan adalah termometer ruang untuk mengetahui suhu luar dan dalam kandang. c) Lampu pijar. Lampu pijar yang digunakan adalah lampu pijar 15 Watt sebanyak 20 buah yang ditempatkan 1 buah untuk setiap petak kandang untuk penghangat dan penerangan pada tiap petak kandang. d) Timbangan. Timbangan yang digunakan dalam penelitian ini adalah timbangan merek Camry model EK5055 kapasitas $5 \mathrm{~kg}$ dengan kepekaan 1 gram untuk menimbang ayam, pakan dan sisa pakan. e) Obat-obatan, vitamin dan vaksin. Vaksin yang diberikan dalam penelitian ini adalah ND B1, ND La Sota dan Gumboro. Vitamin yang diberikan pada penelitian ini adalah anti stress. Program pemberian vaksin ayam broiler selama pemeliharaan dapat dilihat pada Tabel 3.

\section{Persiapan kandang}

Kandang sebelum digunakan terlebih dahulu dibersihkan dan didesinfeksi 
Tabel 2. Kandungan nutrien pakan BR 1 dan BR 2 produksi PT. Japfa Comfeed Indonesia, Tbk.

\begin{tabular}{clll}
\hline \hline No. & \multicolumn{1}{c}{ Nutrien } & \multicolumn{1}{c}{ BR 1 } & \multicolumn{1}{c}{ BR 2 } \\
\hline 1. & Air & Maks. 12\% & Maks. 12\% \\
2. & Protein Kasar & Min. 21\% & Min. 19\% \\
3. & Lemak Kasar & $3-7 \%$ & $3-8 \%$ \\
4. & Serat Kasar & Maks. 5\% & Maks. 5\% \\
5. & Abu & Maks. 7\% & Maks. 7\% \\
6. & Kalsium & $0,9-1,1 \%$ & $0,9-1,1 \%$ \\
7. & Fosfor & $0,6-0,9 \%$ & $0,6-0,9 \%$ \\
8. & Koksidiostat & + & + \\
9. & Antibiotika & + & + \\
\hline
\end{tabular}

Sumber: Label pakan BR 1 dan BR 2 produksi PT. Japfa Comfeed Indonesia, Tbk. Unit Sidoarjo

menggunakan formalin dengan kadar 1 liter dalam 30 liter air. Desinfeksi bertujuan untuk menjaga kebersihan kandang dan sanitasi kandang dari mikrobia patogen. Kegiatan lain yang dilakukan adalah pembersihan dan pengapuran lantai kandang, serta memberi penyekat. Untuk pencucian peralatan, seperti tempat pakan dan tempat minum dilakukan dengan merendamnya dalam larutan rodalon $15 \mathrm{ml}$ dalam 10 liter air dan mengeringkannya di bawah sinar matahari. Sekam sebagai liter ikut difumigasi.

Pada saat akan melakukan perlakuan, ayam broiler umur 15 hari ditimbang kemudian di masukkan kedalam petak kandang secara acak.

\section{Penentuan petak kandang}

Penentuan petak kandang dilakukan untuk menentukan petak perlakuan yaitu dengan cara acak pengundian.

\section{Cara Penelitian}

\section{Macam penelitian}

Penelitian mengenai berbagai tingkat pembatasan pemberian pakan terhadap performans ayam broiler, dilakukan secara eksperimental. Penelitian ini mulai dilaksanakan pada saat ayam berumur 15 hari, dengan melaksanakan pembatasan pakan dengan cara pemuasaan sesuai dengan perlakuan masing-masing. Pembersihan tempat minum di lakukan setiap pagi dan sore, Pengukuran suhu dilaksanakan pada pukul 06.00 WIB, 12.00 WIB, dan 18.00 WIB.

\section{Rancangan percobaan}

Rancangan yang digunakan adalah Rancangan Acak Lengkap (RAL) pola searah dengan empat perlakuan (P0, P1, P2, P3) dan lima kali ulangan untuk setiap perlakuan. Perlakuan pembatasan pakan dilakukan pada ayam umur 15- 42 hari. Masing-masing ulangan berisi lima ekor ayam broiler. Macam perlakuan sebagai berikut :

$\mathrm{P} 0=$ Pemberian pakan secara penuh tanpa puasa

$\mathrm{P} 1=6$ hari pakan penuh dan 1 hari puasa

$\mathrm{P} 2=5$ hari pakan penuh dan 1 hari puasa

$\mathrm{P} 3=4$ hari pakan penuh dan 1 hari puasa

\section{Peubah penelitian}

Peubah yang diukur dan diambil datanya dalam penelitian ini adalah sebagai berikut : a) Pertambahan berat badan PBB). Pertambahan berat badan merupakan selisih bobot badan awal dan bobot akhir selama penelitian yang dinyatakan dalam gram/ekor/hari (Rasyaf, 1994). b) Konsumsi pakan. Konsumsi pakan dihitung dengan cara menimbang jumlah pakan yang diberikan dikurangi dengan sisa pakan selama penelitian yang dinyatakan dalam 
Tabel 3. Program pemberian vaksin ayam broiler selama pemeliharaan

\begin{tabular}{ccc}
\hline \hline Umur (hari) & Obat/Vaksin yang diberikan & Cara Pemberian \\
\hline 4 & Vaksin ND B1 & Tetes mata \\
9 & Vaksin Gumboro B & Air minum \\
18 & Vaksin ND La Sota & Air minum \\
\hline
\end{tabular}

gram/ekor/hari (Rasyaf, 1994). c) Konversi pakan. Konversi pakan dihitung dengan cara membagi jumlah pakan yang dikonsumsi dengan pertambahan berat badan selama perlakuan (Rasyaf, 1994). d) Income Over Feed Cost (IOFC). Penentuan pendapatan didasarkan atas perkalian antara hasil produksi peternakan (dalam kilogram hidup) dengan harga perkilogram produk dikurangi biaya pakan (Rasyaf, 1994).

$\mathrm{PBB}=\frac{\text { Bobot akhir }- \text { bobot awal (g/ekor) }}{\text { Waktu (hari) }}$

Konsumsi pakan $=$ Pakan yang diberikan pakan tersisa

Konversi pakan $=$ Pakan yang dikonsumsi (g/ekor) : Pertambahan berat badan ( $\mathrm{g} / \mathrm{hari})$

$\mathrm{IOFC}=$ Jumlah pendapatan - biaya pakan

\section{Pelaksanaan penelitian}

Pengambilan data konsumsi pakan diambil setiap hari. Pengumpulan data pertambahan berat badan (PBB), konversi pakan, efisiensi pakan dilakukan seminggu sekali. Penelitian ini dilaksanakan selama 42 hari.

\section{Cara Analisis Data}

Semua data yang diperoleh dalam penelitian ini dianalisis menggunakan analisa variansi berdasarkan Rancangan Acak Lengkap (RAL) pola searah untuk mengetahui adanya pengaruh perlakuan terhadap peubah yang diamati. Model matematika yang digunakan adalah sebagai berikut:

$$
\mathbf{Y}_{\mathrm{ij}}=\mu+\tau_{\mathrm{i}}+\epsilon_{\mathrm{ij}}
$$

Keterangan:

$\mathrm{Y}_{\mathrm{ij}}$ : Nilai pengamatan perlakuan ke-I dan ulangan ke-j

$\mu \quad$ : Nilai tengah umum

$\tau_{\mathrm{I}} \quad$ : Pengaruh perlakuan ke-i

$\epsilon_{\mathrm{ij}}$ : Galat percobaan pada perlakuan ke-I ulangan ke-j

Apabila diperoleh hasil yang berbeda nyata dilanjutkan dengan uji Polynomial Orthogonal (Sastrosupadi, 2000).

\section{HASIL DAN PEMBAHASAN}

\section{Pertambahan Bobot Badan}

Rerata pertambahan berat badan harian ayam broiler pada penelitian ini ditunjukkan pada Tabel 4. Berat badan akhir merupakan suatu hasil akhir dari proses pertumbuhan dan laju pertumbuhan, ditunjukkan dengan pertambahan bobot badan. Berdasarkan data pertambahan berat badan (Tabel 4), diketahui bahwa rerata PBB menunjukkan perbedaan yang sangat nyata $(\mathrm{P}<0,01)$ diantara perlakuan $\mathrm{P} 0, \mathrm{P} 1, \mathrm{P} 2$, dan P3. Rerata PBB untuk P0, P1, P2, dan P3 berturut-turut adalah $81.37 ; 74.47 ; 72.65$, dan 72.50 g/ekor/hari. Adapun PBB untuk P1, P2, dan P3 adalah lebih rendah jika dibandingkan dengan $\mathrm{P} 0$, yang disebabkan oleh ayam pada perlakuan P0 tidak dilakukan pemuasaan.

Pada perlakuan P0 ayam tersebut diberi pakan secara ad libitum, sehingga menghasilkan pertambahan berat badan yang lebih tinggi dibandingkan dengan P1, P2, dan P3, karena pada perlakuan P1, P2, dan 
Tabel 4. Rerata pertambahan bobot badan harian ayam broiler selama penelitian (g/ekor/hari)

\begin{tabular}{ccccccc}
\hline \multirow{2}{*}{ Perlakuan } & \multicolumn{5}{c}{ Ulangan } & \multirow{2}{*}{ Rata-rata } \\
\cline { 2 - 5 } & 1 & 2 & 3 & 4 & 5 & \\
\hline P0 & 89,60 & 81,29 & 80,50 & 77,61 & 77,84 & $81,37^{\mathrm{A}}$ \\
P1 & 69,57 & 76,65 & 77,99 & 72,91 & 75,24 & $74,47^{\mathrm{B}}$ \\
P2 & 75,16 & 75,16 & 71,27 & 71,26 & 70,41 & $72,65^{\mathrm{B}}$ \\
P3 & 72,41 & 76,07 & 68,34 & 72,43 & 73,27 & $72,50^{\mathrm{B}}$ \\
\hline Knnnnnnn
\end{tabular}

Keterangan: Superskrip yang berbeda menunjukkan perbedaan yang sangat nyata $(\mathrm{P}<0,01)$

P3 dilakukan pembatasan pakan, sehingga jumlah pakan yang masuk ke dalam tubuh cenderung lebih sedikit dibandingkan P0, serta nutrisi yang ada jumlahnya lebih terbatas. Pada buku standar New Lohmann (MB 202) pertambahan bobot badan ratarata adalah 80,33 g/ekor/hari, sedangkan pada perlakuan $\mathrm{P} 0, \mathrm{P} 1, \mathrm{P} 2$, dan $\mathrm{P} 3$ rataratanya adalah 81,$37 ; 74,47 ; 72 ; 65$; dan 72,50. Pada ayam, energi digunakan untuk hidup dan produksi (pembentukan daging). Biasanya, energi yang diperoleh ayam tidak memenuhi jumlah yang dibutuhkan untuk produksi, sehingga energi yang ada diutamakan untuk menyelamatkan hidupnya terlebih dahulu (memenuhi kehidupan pokoknya). Bila kasus kekurangan energi terus terjadi, ayam akan menggunakan cadangan energinya terlebih dahulu (cadangan energi ini tersimpan dalam bentuk lemak di beberapa bagian tubuhnya). Cadangan energi ini diambil dari depo-depo lemak. Energi yang ada di dalam makanan itu tidak semuanya digunakan, tetapi sebagian terbuang dalam bentuk tinja, atau terbuang melalui urine, dan ada yang diambil oleh alat pencernaan, sehingga sisanya dinamakan energi metabolisme (ME) (Rasyaf, 1994).

Selama pertumbuhan, kebutuhan energi untuk ayam-ayam jantan hanya berbeda sedikit dengan ayam-ayam betina. Penggunaan energi untuk pertumbuhan yang cepat pada ayam jantan, menyebabkan penimbunan lemak yang rendah, jika dibandingkan dengan ayam betina (Wahju, 1988). Menurut (Rasyaf, 1995), pengurangan konsumsi pakan berakibat berkurangnya sejumlah unsur nutrisi yang masuk kedalam tubuh, dan mempunyai dampak lanjutan tidak terpenuhinya kebutuhan sejumlah unsur nutrisi, terutama protein. Pengurangan konsumsi pakan akan mengakibatkan pertumbuhan tidak sesuai dengan standar yang ditetapkan.

Azis et al., (2011), mengemukakan bahwa penurunan pertambahan bobot badan dapat terjadi, antara lain karena: terbatasnya suplai nutrisi, dan energi untuk menunjang pertumbuhan jaringan, penurunan hormon tiroksin, penurunan aktivitas enzim yang berhubungan dengan pencernaan protein. Menurut Tillman et al., (1991), bila hewan tidak menerima pakan, maka cadangan karbohidrat, lemak, dan protein tubuh digunakan untuk menghasilkan energi, guna menjalankan fungsi-fungsi dalam tubuh yang penting. Protein yang seharusnya digunakan untuk pertumbuhan digunakan juga sebagai sumber energi sehingga pertumbuhan bisa terhambat (Maulida, 2004).

\section{Konsumsi pakan}

Rerata Konsumsi pakan ayam broiler pada penelitian ini ditunjukkan pada Tabel 5 . Tabel 5 memperlihatkan rerata konsumsi pakan hasil penelitian untuk perlakuan $\mathrm{P} 0$, P1, P2, dan P3 berturut-turut adalah 137,$944 ; 126,456 ; 124,056$; dan 119,106 g/ekor/hari. Hasil analisis variansi menunjukkan perbedaan yang sangat nyata $(\mathrm{P}<0,01)$. Hal ini berarti bahwa pembatasan pemberian pakan dengan cara pemuasaan mempengaruhi konsumsi pakan. Pembatasan pemberian pakan akan menyebabkan penurunan konsumsi pakan, akan tetapi pembatasan pakan sampai 20 persen, konsumsi pakan masih memungkinkan 
Tabel 5. Rerata Konsumsi Pakan Ayam Broiler Selama Penelitian (g/ekor/hari)

\begin{tabular}{ccccccc}
\hline \hline \multirow{2}{*}{ Perlakuan } & \multicolumn{7}{c}{ Ulangan } & \multirow{2}{*}{ Rata-rata } \\
\cline { 2 - 6 } & 1 & 2 & 3 & 4 & 5 & \\
\hline P0 & 136,95 & 137,70 & 138,05 & 136,69 & 140,06 & $137,944^{\mathrm{B}}$ \\
P1 & 120,57 & 125,38 & 127,19 & 127,73 & 131,41 & $126,456^{\mathrm{B}}$ \\
P2 & 123,77 & 126,78 & 126,25 & 123,83 & 119,65 & $124,056^{\mathrm{B}}$ \\
P3 & 118,31 & 118,33 & 118,09 & 120,13 & 120,67 & $119,106^{\mathrm{A}}$ \\
\hline
\end{tabular}

Keterangan: Superskrip yang berbeda menunjukkan perbedaan yang sangat nyata $(\mathrm{P}<0,01)$

untuk memenuhi kebutuhan, termasuk didalamnya untuk pertumbuhan daging (Mugiyono, 1995 cit. Maulida, 2004).

Konsumsi pakan dipengaruhi oleh ukuran tubuh, aktivitas ternak, temperatur kandang, dan kualitas pakan saat pemeliharaan (Siregar et al., 1980). Menurut Wahju (1988) ternak mengkonsumsi pakan untuk memenuhi kebutuhan akan energi dan nutrien lainnya dalam tubuh. Hal ini sangat ditentukan oleh kandungan energi, serta imbangan nutrien yang ada didalamnya. Menurut Rasyaf (1994), temperatur yang tinggi akan memperlihatkan penurunan konsumsi, dan sebaliknya temperatur lingkungan yang rendah akan memperlihatkan peningkatan konsumsi pakan.

\section{Konversi pakan}

Rerata Konsumsi pakan ayam broiler pada penelitian ini ditunjukkan pada Tabel 6. Pada Tabel 6 memperlihatkan bahwa rata-rata konversi pakan ayam broiler yang dihasilkan selama penelitian untuk perlakuan $\mathrm{P} 0, \mathrm{P} 1, \mathrm{P} 2$, dan $\mathrm{P} 3$ masing-masing yaitu 1,$70 ; 1,70 ; 1,71 ;$ dan 1,64. Hasil analisis variansi menunjukkan pengaruh perlakuan terhadap konversi pakan yang berbeda tidak nyata. Hal ini berarti pembatasan pemberian pakan dengan cara pemuasaan tidak mempengaruhi nilai konversi pakan ayam broiler.

Ayam broiler yang diberi pakan P0 (pemberian pakan penuh tanpa puasa), P1(4 hari pakan penuh dan 1 hari puasa), P2 (5 hari pakan penuh dan 1 hari puasa), P3 (6 hari pakan penuh dan 1 hari puasa), relatif mampu memanfaatkan pakan yang sama dan efisiensi ditandai nilai konversi pakan yang sama pula. Pemberian pakan secara periodik memberikan hasil yang berbeda tidak nyata terhadap nilai konversi pakan. Perlakuan P0 mempunyai konversi pakan yang paling rendah yaitu 1,64 . Konversi pakan menurut Irawan (1996), di pengaruhi oleh beberapa faktor antara lain di pengaruhi oleh jenis ternak, keadaan kandang (lingkungan), jenis kelamin, dan umur. Jenis ternak, keadaan kandang (lingkungan), jenis kelamin, dan umur ternak dalam penelitian ini sama, sehingga konversi pakannya pun tidak berbeda. Ayam broiler dengan umur yang sama relatif memiliki kemampuan mencerna yang sama, sehingga konversi pakannya tidak berbeda.

\section{Income Over Feed Cost (IOFC)}

Rerata Income Over Feed Cost

Tabel 6. Rerata konversi pakan ayam broiler selama penelitian

\begin{tabular}{cllcccc}
\hline \hline & \multicolumn{5}{c}{ Ulangan } & \multirow{2}{*}{ Rata-rata } \\
\cline { 2 - 5 } Perlakuan & 1 & 2 & 3 & 4 & 5 & \\
\hline P0 & 1,53 & 1,69 & 1,71 & 1,76 & 1,80 & 1,70 \\
P1 & 1,73 & 1,64 & 1,63 & 1,75 & 1,75 & 1,70 \\
P2 & 1,65 & 1,69 & 1,77 & 1,74 & 1,70 & 1,71 \\
P3 & 1,63 & 1,56 & 1,73 & 1,66 & 1,65 & 1,64 \\
\hline
\end{tabular}

Keterangan: Berbeda tidak nyata 
Tabel 7. Rerata Income Over Feed Cost (IOFC) ayam broiler selama penelitian (Rp)

\begin{tabular}{ccccccc}
\hline \hline \multirow{2}{*}{ Perlakuan } & \multicolumn{5}{c}{ Ulangan } & \multicolumn{2}{c}{ Rata-rata } \\
& 1 & 2 & 3 & 4 & 5 & \\
\hline P0 & $9.664,27$ & $8.749,43$ & $8.661,73$ & $8.345,03$ & $8.365,84$ & $8.757,26$ \\
P1 & $7.484,05$ & $8.255,97$ & $8.401,15$ & $7.841,75$ & $8.091,95$ & $8.014,98$ \\
P2 & $8.094,79$ & $8.090,58$ & $7.663,10$ & $7.664,92$ & $7.577,27$ & $7.818,14$ \\
P3 & $7.799,14$ & $8.202,19$ & $7.351,60$ & $7.798,96$ & $7.890,91$ & $7.808,57$ \\
\hline
\end{tabular}

(IOFC) ayam broiler pada penelitian ini ditunjukkan pada Tabel 7. Berdasarkan Tabel 7 rerata pendapatan atas biaya pakan hasil penelitian untuk $\mathrm{P} 0, \mathrm{P} 1, \mathrm{P} 2$, dan $\mathrm{P} 3$ berturut-turut adalah $\mathrm{Rp} 8.757,26 ; \mathrm{Rp}$ 8.014,98; Rp 7.818,14; dan Rp 7.808,57.

Berat badan ayam broiler sangat mempengaruhi pendapatan atas ayam broiler. Perlakuan P0, P1, dan P2 memberikan pendapatan yang lebih tinggi dibandingkan P3.

Berat badan ternak yang semakin menurun menyebabkan harga penjualan menurun. Penurunan pendapatan tersebut disebabkan harga penjualan ayam broiler tidak berdasarkan perekor akan tetapi berdasarkan bobot badan, sehingga ayam broiler dengan perlakuan P0, P1, P2, dan P3 memberikan harga yang berbeda. Pada penelitian ini Income Over Feed Cost yang terbaik terdapat pada P0, karena P0 mempunyai bobot badan yang paling tinggi, sehingga pendapatan tersebut disebabkan oleh harga penjualan ayam broiler tidak bedasarkan perekor, akan tetapi berdasarkan bobot badan. Hal ini di dukung Rasyaf (1994), bahwa pendapatan atas ayam broiler dipengaruhi oleh harga pakan dan harga penjualan ayam broiler, semakin efisien mengubah ransum menjadi daging, semakin baik pula Income Over Feed Cost (IOFC). Dalam pengelolaan usaha peternakan ayam broiler, pertumbuhan ekonomi selalu menjadi prioritas utama, disebabkan oleh biaya produksi terutama biaya pakan yang mencapai $70 \%$ dari total biaya produ (Siregar et al., 1980). Pembatasan pemberian pakan khususnya dengan metode pemuasaan bertujuan untuk menekan biaya produksi dan meningkatkan efisiensi penggunaan ransum (Haryanto, 1998 cit. Maulida, 2004).

\section{KESIMPULAN}

Kesimpulan yang diperoleh dalam penelitian ini adalah :

1. Tingkat pembatasan pemberian pakan (Restricted feeding) mempengaruhi konsumsi pakan dan pertambahan berat badan ayam broiler jantan. Ayam broiler jantan yang tidak di puasakan memberikan hasil pertambahan berat badan yang terbaik.

2. Ayam broiler jantan yang tidak dipuasakan mempunyai bobot badan yang paling tinggi, sehingga mempunyai pendapatan yang paling tinggi jika dilihat dari Income Over Feed Cost, hal tersebut disebabkan harga penjualan ayam broiler berdasarkan bobot badan.

\section{SARAN}

Sebaiknya perlu dilakukan penelitian pembatasan pakan (Restricted feeding) dengan variasi-variasi pemuasaan yang lainnya.

\section{DAFTAR PUSTAKA}

Azhar, M. 2010. Evaluasi Program Pemuasaan Berselang pada Ayam Pedaging (Evaluation of Skip a Day Feed Removal Programme on the Broiler Chicken). Didownload: http://chytoxx.blogspot.com/2010/05/ evaluasi-program- evaluasi berselang.html, Pada tanggal 11 Februari 2011.

Azis, A., H. Abbas, Y. Heryandi dan E. Kusnadi. 2011. Pertumbuhan Kompensasi dan Efisiensi Produksi Ayam Broiler yang Mendapat Pembatasan Waktu Makan. Media 
Peternakan, April 2011, hlm. 50-57. EISSN 2087 - 4634.

Darmawati. 2005. Pemberian Pakan Terbatas secara Periodic pada Ayam Pedaging (Lenghorn). Jurnal Biogenesis Vol. 1(2): 43-46, 2005.

Irawan, A. 1996. Ayam-ayam Pedaging Unggul. CV.Aneka Ilmu. Solo.

Maulida. 2004. Pengaruh Pembatasan Pakan Terhadap Performan, Bobot Karkas Dan Non Karkas Pada Itik Afkhir. Skripsi Jurusan Produksi Ternak Fakultas Pertanian. Universitas Sebelas Maret.

NRC. 1994. Nutrient Requirements of Poultry. National Academy Press. Washington D.C.

Rasyaf, M. 1994. Beternak Ayam Pedaging. Penebar Swadaya. Jakarta 1995. Pengelolaan Usaha Peternakan Ayam Pedaging. Gramedia. Jakarta.

Santoso, U. 2008. Aplikasi Industri Pembatasan Pakan pada Industri Broiler. http://uripsantoso.wordpress.com/20 08/05/03/aplikasi-teknologipembatasan-pakan-pada-industribroiler/, Diakses tanggal 11 Februari 2011.

Sastrosupadi, A. 2000. Rancangan Percobaan Praktis Bidang Pertanian. Kanisius. Yogyakarta.

Siregar, A. P., M. Sabrani dan P. Suraprawiro. 1980. Tehnik Beternak Ayam Pedaging di Indonesia. Margie Group. Jakarta.

Suprijatna, E., U. Atmomarsono., dan R. Kartasudjana. 2005. Ilmu Dasar Ternak Unggas. Penebar Swadaya. Jakarta.

Tillman, A. D., H. Hartadi, S. Reksohadiprodjo, S. Prawirokusumo dan S. Lebdosoekojo. 1991. Ilmu Makanan Ternak Dasar. Gadjah Mada University Press. Yogyakarta.

Wahju, J. 1988. Ilmu Nutrisi Unggas. Cetakan Kedua.. Gadjah Mada University Press. Yogyakarta. 